Optical characterization of Sol-Gel ZnO:Al thin films

This content has been downloaded from IOPscience. Please scroll down to see the full text. 2016 J. Phys.: Conf. Ser. 700012048

(http://iopscience.iop.org/1742-6596/700/1/012048)

View the table of contents for this issue, or go to the journal homepage for more

Download details:

IP Address: 139.165.209.80

This content was downloaded on 03/06/2016 at $16: 32$

Please note that terms and conditions apply. 


\title{
Optical characterization of Sol-Gel ZnO:Al thin films
}

\author{
T Ivanova $^{1}$, A Harizanova ${ }^{1,4}$, T Koutzarova ${ }^{2}$ and B Vertruyen ${ }^{3}$ \\ ${ }^{1}$ Central Laboratory of Solar Energy and New Energy Sources, \\ Bulgarian Academy of Sciences, 72 Tzarigradsko Chaussee, 1784 Sofia, Bulgaria \\ ${ }^{2}$ Emil Djakov Institute of Electronics, Bulgarian Academy of Sciences, \\ 72 Tzarigradsko Chaussee, 1784 Sofia, Bulgaria \\ ${ }^{3}$ LCIS/SUPRATECS, Institute of Chemistry B6, University of Liege, \\ Sart-Tilman, B-4000 Liege, Belgium \\ E-mail: tonyhari@phys.bas.bg
}

\begin{abstract}
This paper presents a sol-gel technological process for preparing thin films of $\mathrm{ZnO}$ and $\mathrm{ZnO}: \mathrm{Al}$. The effect of annealing treatments $\left(500,600,700\right.$ and $\left.800{ }^{\circ} \mathrm{C}\right)$ on their properties was studied. The structural evolution with the temperature was investigated by using X-Ray diffraction (XRD). Fourier Transform Infrared (FTIR) and UV-VIS spectrophotometry were applied to characterizing the films' vibrational and optical properties. The $\mathrm{ZnO}$ and $\mathrm{ZnO}: \mathrm{Al}$ films possessed a polycrystalline structure. The films studied are highly transparent in the visible spectral range. The optical band gap values and the haze parameter were also determined.
\end{abstract}

\section{Introduction}

Nanostructured metal oxide films have been extensively studied due to their numerous applications, especially in optoelectronics. Among these materials, $\mathrm{ZnO}$ has prompted extensive scientific research with respect to its interesting properties, such as a wide band gap $(3.37 \mathrm{eV})$ with a large exciton binding energy $(60 \mathrm{meV})$, a high chemical stability, a low dielectric constant, a high thermal conductivity, antibacterial and UV protection properties [1]. On the other hand, the $\mathrm{ZnO}$ thin films exhibit a high transmittance in the infrared and visible spectral regions and a high refractive index, which extends their application range [2]. ZnO films are used as transparent conductors, chemical and biological gas sensors, ultraviolet light emitters, thin film transistors, solar cell windows [3-4].

Doping and mixing $\mathrm{ZnO}$ with different metals leads to changing and enhancing some of their electronic and optical properties. Recently, Al, P, N, Mg, Sb, Mn, B etc. [5] have been studied extensively as promising dopants for $\mathrm{ZnO}$ using various technological approaches. Aluminium-doped zinc oxide coatings manifest high transparency and low resistivity [6]. The doping concentration influences the optical and structural properties. The sol-gel technology offers the possibility to produce high-quality homogeneous thin films over a large area, excellent control of the stoichiometry, composition modification (mixing on a molecular level), a cost-effective process, and inexpensive equipment. [7].

\footnotetext{
${ }^{4}$ To whom any correspondence should be addressed.
} 
This paper presents a sol-gel method for depositing $\mathrm{ZnO}$ and $\mathrm{ZnO}: \mathrm{Al}$ thin films. The effect of the doping concentrations of $\mathrm{Al}$ on the optical and structural properties is investigated. The influence of the annealing temperature is also studied. The measurement techniques used are XRD, FTIR and UV-VIS spectrophotometry.

\section{Experimental}

Two sol solutions were prepared for depositing $\mathrm{ZnO}$ and $\mathrm{Al}_{2} \mathrm{O}_{3}$ films. They were synthesized as follows:

Solution 1) Zinc acetate was dissolved in absolute ethanol (0.4 M concentration). The complexing agent and stabilizer was monoethanolamine $(\mathrm{MEA} / \mathrm{Zn}$ molar ratio $=1)$;

Solution 2) Alumina-sec-butoxide was dissolved in isopropyl alcohol (0.2 M concentration). Acetylacetone was used as chelating agent. The full details are given in [8].

The two sol solutions were found to be stable and to retain their film forming properties for more than three months. The mixing of the two sols was made in molar ratios ( $\mathrm{Al} \mathrm{sol} / \mathrm{Zn}$ sol) of $0.01,0.03$, 0.05 and 0.1 ; the films thus prepared are referred to with these names throughout the text. The films were deposited by spin coating at $4000 \mathrm{rpm}$ on $\mathrm{Si}$ and quartz substrates; the samples underwent five layer depositions. The preheating temperature was $300{ }^{\circ} \mathrm{C} / 10 \mathrm{~min}$. After repeating the coating procedures five times, the films were annealed at $500,600,700$ and $800{ }^{\circ} \mathrm{C}$ in air for one hour.

The XRD spectra of the sol-gel films were recorded by a Bruker D8 XRD diffractometer at the grazing angle of $2^{\circ}$, a step time of $8 \mathrm{~s}$ at a step of $0.1^{\circ}$. The FTIR measurements were performed on an IRPrestige-21 Shimadzu FTIR Spectrophotometer. The optical measurements were conducted by using a UV-VIS-NIR Shimadzu 3600 spectrophotometer in direct, diffuse and total transmittance modes.

\section{Results and discussions}

The XRD spectra of $\mathrm{ZnO}$ and $\mathrm{ZnO}: \mathrm{Al}(0.01)$ films are presented in figure 1 after thermal treatments at different temperatures. The five strongest lines are assigned to a wurtzite phase (JCPDS 01-07-8070). The corresponding lines for $\mathrm{ZnO}: \mathrm{Al}$ (0.01) films appear with lower intensities suggesting that the crystallization has decayed. This means that the $\mathrm{Al}$ additive affects the films' crystalline structure.
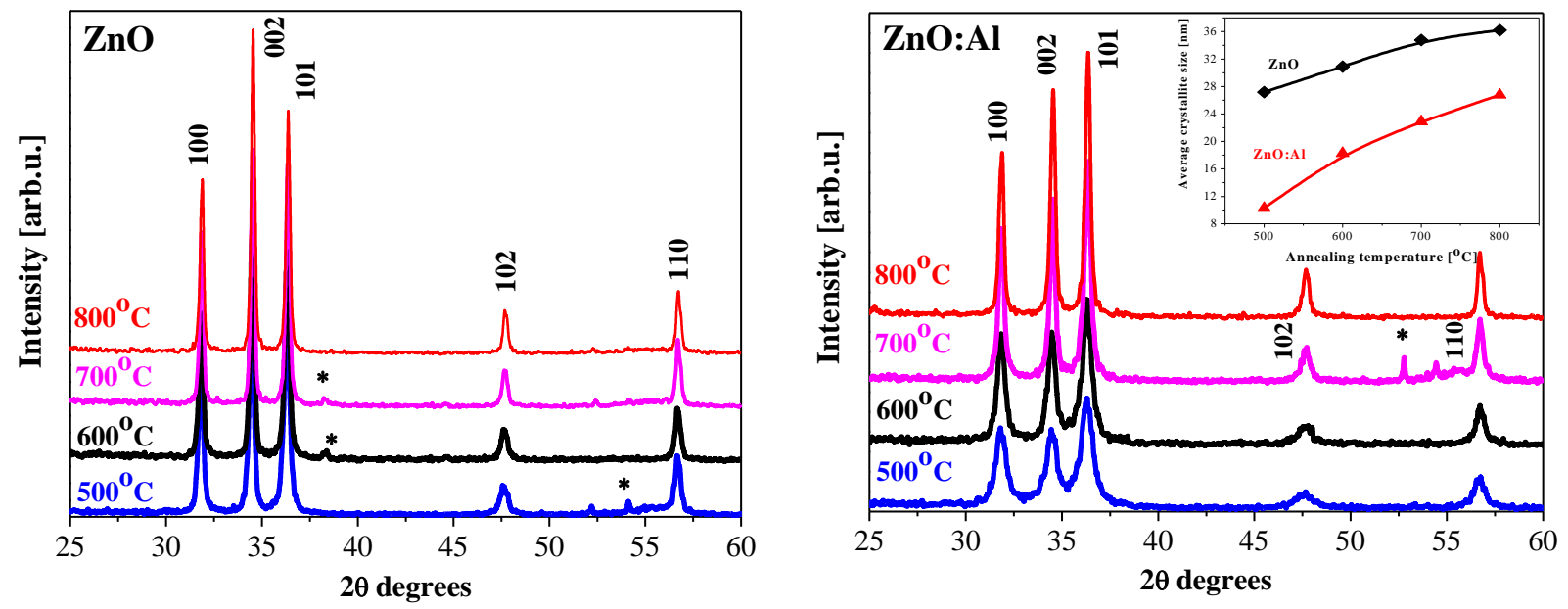

Figure 1. XRD spectra of $\mathrm{ZnO}$ and $\mathrm{ZnO}: \mathrm{Al}(0.01)$ films. The asterisks show lines due to $\mathrm{ZnO}_{2}$.

The $\mathrm{ZnO}$ film annealed at $500{ }^{\circ} \mathrm{C}$ shows five intense peaks of wurtzite $\mathrm{ZnO}$ and a small line at $2 \theta=54.1$, attributed to the $\mathrm{ZnO}_{2}$ cubic phase (200) (JCPDS 13-0311). The $\mathrm{ZnO}$ :Al film $\left(500{ }^{\circ} \mathrm{C}\right)$ manifests XRD lines corresponding to wurtzite only. The $\mathrm{ZnO}$ film $\left(600{ }^{\circ} \mathrm{C}\right)$ crystallizes in a wurtzite. phase with a weak reflection at 38.4, associated with cubic $\mathrm{ZnO}_{2}$. The thermal treatment at $700{ }^{\circ} \mathrm{C}$ leads to the detection of two additional weak lines in the spectrum of $\mathrm{ZnO}: \mathrm{Al}$ at $2 \theta=54.4$ and 55.6, 
assigned to cubic $\mathrm{ZnO}_{2}$. The highest annealing temperature results in good polycrystalline films with a wurtzite $\mathrm{ZnO}$ crystal phase. The average crystallite sizes are estimated according to Scherrer's formula (for peaks: 100, 002 and 101) and the results obtained are shown in the inset (figure 1) and table 1. The Al component influences the crystallization of the films, namely, the crystallite size significantly diminishes compared to that of $\mathrm{ZnO}$ films. The average crystallite size of $\mathrm{ZnO}$ is $32 \mathrm{~nm}$, while the value for $\mathrm{ZnO}: \mathrm{Al}$ is $20 \mathrm{~nm}$. Table 1 presents also the calculated lattice parameters and the dislocation density of the films. Dislocations are imperfections in a crystal associated with misregistry of the lattice in one part of the crystal with respect to another part. The dislocation density of the films is given by the Williamson and Smallman's relation ([9]): $\delta=n / d^{2}(1)$, where $n$ is a factor equal to unity at the minimum dislocation density and $d$ is the grain size. The dislocation densities decrease as the annealing temperature is raised, which indicates a lower concentration of lattice imperfections.

Table 1. Average crystallite size $(d)$, dislocation density $(\delta)$ and lattice parameters.

\begin{tabular}{|c|c|c|c|c|c|}
\hline Material & $\mathrm{T},\left({ }^{\circ} \mathrm{C}\right)$ & $\mathrm{d}, \mathrm{nm}$ & $\delta \times 10^{-4}\left(1 / \mathrm{nm}^{2}\right)$ & $a(\AA)$ & $c(\AA)$ \\
\hline \multirow[t]{4}{*}{$\mathrm{ZnO}$} & 500 & 27.2 & 13.5 & 3.243 & 5.197 \\
\hline & 600 & 30.9 & 10.5 & 3.243 & 5.193 \\
\hline & 700 & 34.8 & 8.3 & 3.242 & 5.189 \\
\hline & 800 & 36.2 & 7.6 & 3.241 & 5.185 \\
\hline \multirow[t]{4}{*}{$\mathrm{ZnO}: \mathrm{Al}$} & 500 & 10.3 & 94.3 & 3.244 & 5.192 \\
\hline & 600 & 18.3 & 29.9 & 3.242 & 5.200 \\
\hline & 700 & 22.9 & 19.1 & 3.242 & 5.196 \\
\hline & 800 & 26.9 & 13.9 & 3.241 & 5.187 \\
\hline \multicolumn{4}{|c|}{ JCPDS 01-07-8070 card, wurtzite ZnO } & 3.2489 & 5.2049 \\
\hline
\end{tabular}

The lattice parameters $a, c$ of the two materials decrease slightly with the annealing temperature. The XRD study reveals that the degree of crystallization worsens with the addition of Al, resulting in crystallites of a smaller size. The finding that there is no indication of mixed $\mathrm{Zn} / \mathrm{Al}$ oxide phases can imply that the $\mathrm{Al}$ atoms substitute for the zinc in the respective sites or are incorporated in the lattice [10].

FTIR spectroscopy was used as a supplement for revealing the structure of the films studied. FTIR analysis reveals that both the metal additive and the annealing procedures affect the vibrational properties of the films. The absorption bands due to metal-oxygen bonds are expected in the spectral range 350-1200 $\mathrm{cm}^{-1}$ (figure 2). The line around $1100 \mathrm{~cm}^{-1}$ observed in all spectra is due to Si-O bonding. For the ZnO:Al films, weak peaks at 665 and $681 \mathrm{~cm}^{-1}$ are observed, which might be assigned either to $\mathrm{Zn}-\mathrm{O}$ [11] or to O-Al-O bonding [12]. However, a line at $667 \mathrm{~cm}^{-1}$ is also observed in the $\mathrm{ZnO}$ spectra. The main IR lines are located in the spectral range $390-425 \mathrm{~cm}^{-1}$ (see the insets).
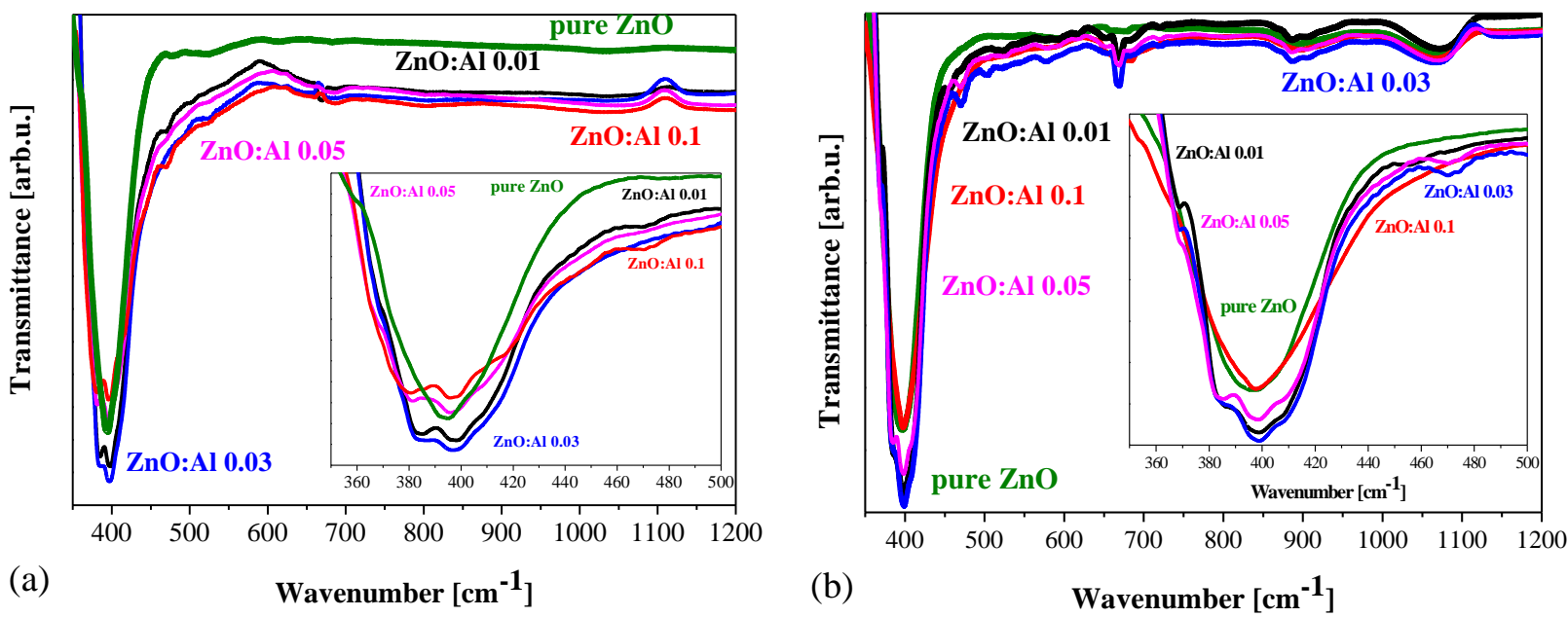

Figure 2. FTIR spectra of sol-gel $\mathrm{ZnO}$ and $\mathrm{ZnO}: \mathrm{Al}$ films annealed at 600 (a) and $800{ }^{\circ} \mathrm{C}$ (b). 
The Al component influences the shapes of the absorption bands. The bands are broader and with different intensities compared to the $\mathrm{ZnO}$ spectra. The IR spectra may be influenced by the crystallite's size, shape and degree of crystallinity and are often used to corroborate the XRD study. Upon addition of $\mathrm{Al}$, the main absorption band shifts from 394 to $400 \mathrm{~cm}^{-1}$. Clear shoulders of the main bands appear at $415 \mathrm{~cm}^{-1}$. They are related to $\mathrm{Zn}-\mathrm{O}$ stretching vibrations. It must be noted that there are no clearly identified absorption bands that are connected with vibrations of the Al-O bonds. This conclusion is in agreement with the XRD study, where the only detected crystalline phase is wurtzite $\mathrm{ZnO}$.
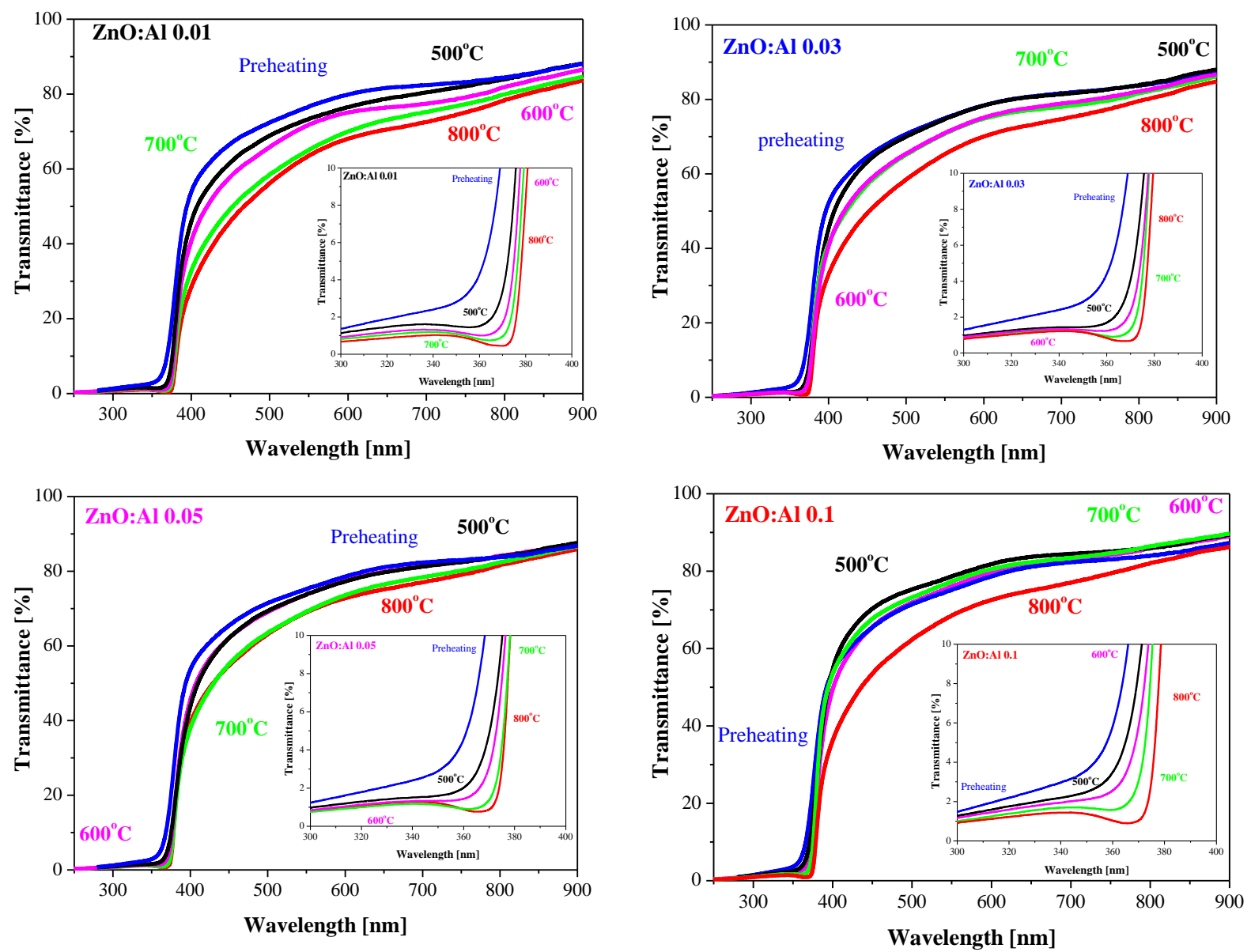

Figure 3. Transmittance spectra of sol-gel $\mathrm{ZnO}: \mathrm{Al}$ films annealed at different temperatures.

The optical properties of the sol-gel $\mathrm{ZnO}$ and $\mathrm{ZnO}: \mathrm{Al}$ films were also investigated; the transmittance spectra are presented in figure 3. The $\mathrm{ZnO}$ films possess a lower transparency compared to $\mathrm{ZnO}: \mathrm{Al}$ films; their transmittance decreases as the annealing temperature is raised. The $\mathrm{ZnO}: \mathrm{Al}$ films demonstrate the same tendency of decreasing the transmittance after higher temperature annealing.

Our previous study [13] showed that as a higher amount of the $\mathrm{Al}$ component was introduced to the sol solution, the films produced exhibited a significantly higher transparency in the visible spectral range. This effect is more clearly pronounced for $\mathrm{ZnO}: \mathrm{Al} 0.05$ and $\mathrm{ZnO}: \mathrm{Al} 0.1$, as can be seen in figure 4.

The specific bands in the optical spectra below the absorption edge are due to the excitonic absorption of $\mathrm{ZnO}$ (insets in figures 3 and 4). The bulk $\mathrm{ZnO}$ excitonic feature is located at $373 \mathrm{~nm}$ [14]. The appearance of an excitonic peak is a sign of the degree of $\mathrm{ZnO}$ crystallinity. Respectively, 


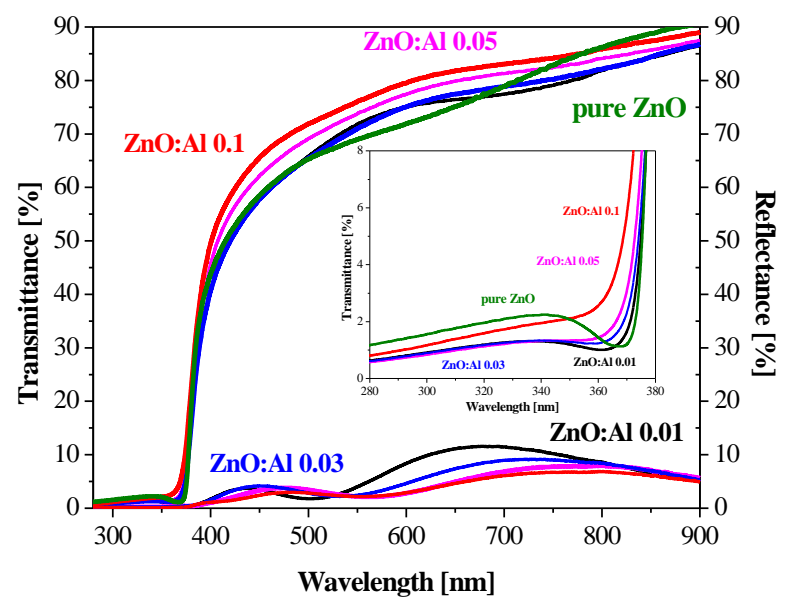

Figure 4. Comparison of transmittance and reflectance spectra of $\mathrm{ZnO}$ and $\mathrm{ZnO}: \mathrm{Al}$ films annealed at $600^{\circ} \mathrm{C}$. the excitonic absorptions prove that the $\mathrm{ZnO}: \mathrm{Al}$ films are less crystalline compared to the $\mathrm{ZnO}$ thin films, as it has been found by the XRD analysis.

The excitonic absorptions of $\mathrm{ZnO}$ are found to be in the range of 331 to $347 \mathrm{~nm}$. The ZnO:Al films show excitonic absorptions only after annealing at 700 and $800^{\circ} \mathrm{C}$. This is due to the smaller degree of crystallization of the $\mathrm{ZnO}$ :Al films annealed at lower temperatures, as has been proved by the XRD study.

Table 2 shows the values of the optical band gap $E_{\mathrm{g}}$ of $\mathrm{ZnO}$; there is no clear trend of an increase or a decrease of the values observed after annealing at different temperatures. The optical band gap of $\mathrm{ZnO}: \mathrm{Al}$ films decreases with the increase of the annealing temperature. The results are close to those for $\mathrm{ZnO}$ films. It has been found earlier [15] that increasing the $\mathrm{Al}$ component results in a widening of $E_{\mathrm{g}}$ due to the lower degree of crystallization and/or formation of $\mathrm{Zn}-\mathrm{Al}-\mathrm{O}$ phases. The optical band gap values of the films studied by us agree with the data reported in [16]. On the other hand, the band gap values of all sol-gel $\mathrm{ZnO}$ and $\mathrm{ZnO}$ :Al films

Table 2. Optical band gap values $[\mathrm{eV}]$ determined from spectrophotometrical data.

\begin{tabular}{lccccc}
\hline & $\mathrm{ZnO}$ & $\mathrm{ZnO}: \mathrm{Al} 0.01$ & $\mathrm{ZnO}: \mathrm{Al} 0.03$ & $\mathrm{ZnO}: \mathrm{Al} 0.05$ & $\mathrm{ZnO}: \mathrm{Al} 0.1$ \\
\hline $\begin{array}{l}\text { Preheating } \\
\text { temperature }\end{array}$ & 3.30 & 3.27 & 3.28 & 3.28 & 3.29 \\
$500^{\circ} \mathrm{C}$ & 3.28 & 3.27 & 3.25 & 3.25 & 3.28 \\
$600^{\circ} \mathrm{C}$ & 3.27 & 3.27 & 3.26 & 3.26 & 3.27 \\
$700^{\circ} \mathrm{C}$ & 3.28 & 3.26 & 3.27 & 3.27 & 3.27 \\
$800^{\circ} \mathrm{C}$ & 3.28 & 3.26 & 3.26 & 3.27 & 3.26 \\
\hline
\end{tabular}

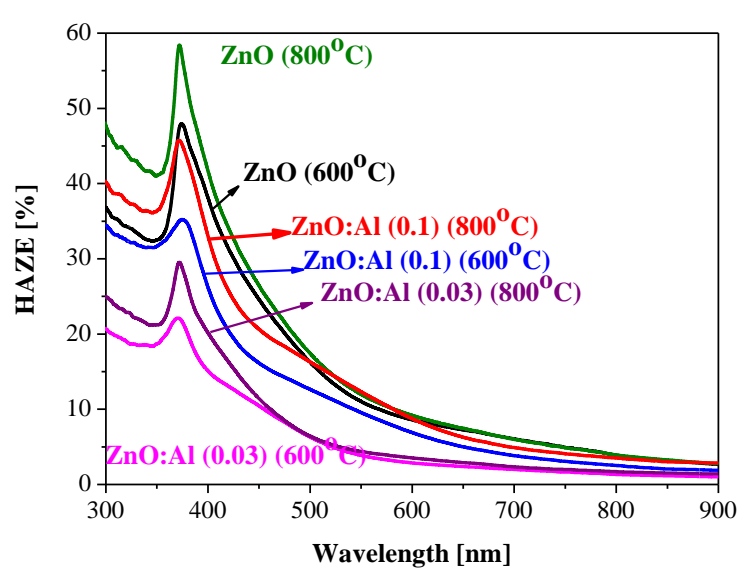

Figure 5. Haze of $\mathrm{ZnO}, \mathrm{ZnO}: \mathrm{Al}(0.03)$ and $\mathrm{ZnO}$ : $\mathrm{Al}(0.1)$ films annealed at 600 and $800{ }^{\circ} \mathrm{C}$. are smaller than the optical band gap of single crystalline $\mathrm{ZnO}(3.37 \mathrm{eV})$. It has also been reported that the lower values of the optical band gap could be due to the presence of growth stress, thermal expansion and mismatch stress.

Another interesting optical property is the haze value. The haze parameter serves as an indicator for the diffuse scattering of light by thin films. The haze parameter for transmitted light is defined as the ratio between the diffuse part of the transmitted light to the total transmitted light. Total and diffuse transmittance spectra were measured using an integral sphere attachment.

Figure 5 shows the haze parameter. It can be seen that the $\mathrm{ZnO}$ films exhibit higher values of 
haze compared to $\mathrm{ZnO}: \mathrm{Al}$. It is interesting to note that the films with a higher content of $\mathrm{Al}$ reveal values higher than those of $\mathrm{ZnO}: \mathrm{Al}(0.1)$. When the $\mathrm{Al}$ component amount is increased in the sol solution, the spectra of the direct and total transmittance are very similar, indicating that the films are very smooth and there is no light scattering.

\section{Conclusions}

In this work, a sol-gel technology was successfully applied to depositing transparent $\mathrm{ZnO}$ and $\mathrm{ZnO}: \mathrm{Al}$ films. The XRD analysis reveals the existence of wurtzite $\mathrm{ZnO}$ and a decrease of the film crystallinity upon $\mathrm{Al}$ doping. The crystallite sizes of $\mathrm{ZnO}$ and $\mathrm{ZnO}$ :Al films differ, as those of the doped films are smaller. No Al containing phases are detected by XRD and FTIR analysis. The optical transmittance is improved for the $\mathrm{ZnO}$ :Al films in comparison with pure $\mathrm{ZnO}$ films. The optical study also reveals that the optical band gap is not significantly changed by $\mathrm{Al}$ addition and thermal treatments. The technological approach proposed for $\mathrm{ZnO}$ : $\mathrm{Al}$ film deposition is very promising.

\section{References}

[1] Poongodi C, Kumar R M and Jayavel R 2015 Ceramics Int. 414169

[2] Tiwari N, Shieh H P D and Liu P T 2015 Mater. Lett. 15153

[3] Chu J, Peng X, Sajjad M, Yang B and Feng P X 2012 Thin Solid Films 5203493

[4] Lim D C, Shim W H, Kim K-D, Seo H O, Lim J-H, Jeong Y, Kim Y D and Lee K H 2011 Solar Energy Mater. Solar Cells $\mathbf{9 5} 3036$

[5] Özgür U, Hofstetter D and Morkoç H 2010 Proc. IEEE 981255

[6] Marotti R E, Bojorge C D, Broitman E, Cánepa H R, Badán J A, Dalchiele E A and Gellman A J 2008 Thin Solid Films 5171077

[7] Aydemir S and Karakaya S 2015 J. Magnetism Magnetic Mater. 37333

[8] Vitanov P, Harizanova A, Ivanova T and Dimitrova T 2009 Thin Solid Films 5176327

[9] Ergin B, Ketenci E and Atay F 2009 Int. J. Hydrogen Energy 345249

[10] Gong L, Ye Zh, Lu J, Zhu L, Huang J, Gu X and Zhao B 2010 Vacuum 84947

[11] Li C P, Jang B H, Wang X C, Li M J, Su L and Li X W 2011 Appl. Surf. Sci. 2575998

[12] Adamczyk A and Długoń E 2012 Spectroch. Acta A 8911

[13] Ivanova T, Harizanova A. Koutzarova T and Vertruyen B 2015 Superlattices Microstr. 85101

[14] Kuo S-Y, Chen W-C and Cheng C P 2006 Superlattices Microstr. 39162

[15] You Q, Cai H, Hu Zh, Liang P, Prucnal S, Zhou Sh, Sun J, Xu N and Wu J 2015 J. Alloys Comp. 644528

[16] Wang M, Lee K, Hahn S, Kim E, Kim S, Shin E and Park C 2007 Mater. Lett. 611118

[17] Yen W T, Lin Y C and Ke JH 2010 Appl. Surf. Sci. 257960 